\title{
Microbial Corrosion of 2205 Duplex Stainless Steel in Oilfield- Produced Water
}

\author{
Wuqi Song, Xu Chen ${ }^{*}$, Chuan He, Xin Li, Chang Liu
}

School of Petroleum Engineering, Liaoning Shihua University, Fushun 113001, PR China

"E-mail: cx0402@sina.com

doi: $10.20964 / 2018.01 .54$

Received: 7 September 2017 / Accepted: 27 October 2017 / Published: 16 December 2017

The microbial corrosion of 2205 duplex stainless steel in oilfield-produced water containing sulfatereducing bacteria (SRB) was studied using scanning electron microscopy, energy-dispersive X-ray spectroscopy microanalysis, and electrochemical techniques. The results showed that SRB growth in the oilfield water injection system could be divided into four periods - viscous growth, logarithmic growth, stable growth, and decay phases-with SRB metabolism affecting the environmental parameters such as $\mathrm{pH}$, conductivity, $\mathrm{S}^{2-}$ concentration. During viscous and logarithmic SRB growth, $\mathrm{SO}_{4}{ }^{2-}$ was reduced to $\mathrm{S}^{2-}$, which combined with $\mathrm{Fe}^{2+}$ to accelerate the corrosion of the steel surface. In the stable growth phase, a protective biofilm was formed on the steel surface, hindering interfacial mass transfer and thereby delaying corrosion. In the decay period, the partial falling off of the microbial film and the degradation of deposited corrosion product and metabolite layers resulted in the formation of a corrosion galvanic cell, accelerating the corrosion process.

Keywords: 2205 DSS, oilfield-produced water, SRB corrosion, growth period, biofilm

\section{$\underline{\text { FULL TEXT }}$}

(C) 2018 The Authors. Published by ESG (www.electrochemsci.org). This article is an open access article distributed under the terms and conditions of the Creative Commons Attribution license (http://creativecommons.org/licenses/by/4.0/). 